\title{
ENVIRONMENTAL INFLUENCES ON WINTERING DUCK ABUNDANCE AT GREAT SALT LAKE, UTAH
}

\author{
Anthony J. Roberts ${ }^{1,3}$, Michael R. Conover ${ }^{1}$, and Josh L. Vest ${ }^{2}$
}

\begin{abstract}
North American waterfowl winter throughout a large geographic area, and the choice of wintering site has a direct impact on survival and fitness. Climatic and food variables are the most commonly cited factors influencing abundance and distribution of wintering migratory birds, including waterfowl. We conducted stratified aerial surveys at a northern latitude wintering site, Great Salt Lake (GSL), Utah, to describe the importance of this wintering area and to examine the influence of weather and food on the abundance of total ducks, Northern Shovelers (Anas clypeata), and goldeneye species (Bucephala spp.). Surveys indicated that up to 270,000 ducks use the GSL during winter, making it an important wintering area in the Pacific Flyway. Peak abundance of total ducks was positively correlated with overwinter temperatures. Northern Shoveler abundance was positively correlated with elevation of the GSL; higher lake elevation indicated more open water and hence more overwintering habitat. Goldeneye abundance was correlated with the continental population of the species and food abundance. All models had moderate fit $\left(r^{2}>0.40\right)$. The GSL is unique in the United States as it is a large body of water where consistent ice cover does not occur and foraging habitat is available to ducks throughout winter. Our results suggest that ambient temperature and habitat availability are primary factors in the abundance of total wintering waterfowl, though food abundance seemed to influence wintering population size of individual duck species. We hypothesize that ducks endure the cold, hypersaline conditions on the GSL to exploit the abundant food supply and remain close to primary breeding regions.
\end{abstract}

Resumen.-Las aves acuáticas de América del Norte pasan el invierno en un área geográfica grande, y la elección del sitio en donde pasan el invierno tiene un impacto directo en la supervivencia y en la adecuación. Las variables climáticas y alimenticias son los factores comúnmente citados que influyen en la abundancia y la distribución de los sitios de invierno de las aves migratorias, incluidas las aves acuáticas. Llevamos a cabo un monitoreo aéreo estratificado en un sitio de invierno en latitud norte, Gran Lago Salado (GSL), Utah, para describir la importancia de este sitio de invierno, y estudiar la influencia del clima y el alimento en la abundancia total de patos, patos cuchara (Anas clypeata), y especies de porrones (Bucephala spp.). Los monitoreos indicaron que hasta 270,000 patos utilizan el GSL durante el invierno, por lo que es un área de invierno muy importante en la ruta migratoria del Pacífico (Pacifico Flyway). La abundancia pico de patos en total se correlacionó positivamente con las temperaturas del invierno. La abundancia de patos cuchara se correlacionó positivamente con la elevación del GSL; elevaciones mayores del lago indicaron más agua abierta y por lo tanto mayor sitio para habitar durante el invierno. La abundancia de porrones se correlacionó con la población continental de cada especie y la abundancia de alimento. Todos los modelos tuvieron un ajuste moderado $\left(r^{2}>0.40\right)$. El GSL es único en los Estados Unidos, ya que es un cuerpo de agua muy grande en donde no se forma una capa de hielo consistente y el hábitat de forrajeo está disponible para los patos durante todo el invierno. Nuestros resultados sugieren que la temperatura del ambiente y la disponibilidad de hábitat son factores primarios en la abundancia total de aves acuáticas en invierno, aunque la abundancia de alimento pareció influenciar el tamaño poblacional durante el invierno de especies de patos. Proponemos que los patos pueden soportar el frio y la hipersalinidad del GSL lo que les ayuda a explotar las fuentes de alimento y así permanecer cerca de las regiones de reproducción primarias.

Wintering waterfowl abundance and distribution can be impacted by numerous factors including food (Miller et al. 2009, Dalby et al. 2013), weather (Nichols et al. 1983, Hepp and Hines 1991, Schummer et al. 2010), ice cover (Ouellet et al. 2010), and interspecific competition (DuBowy 1988). Many ducks winter in North America where there are large areas of habitat with relatively warm temperatures and abundant food sources, such as the Central
Valley of California, the coast of the Gulf of Mexico, and the Mississippi Alluvial Valley. The ability of many waterfowl species to winter at more northerly latitudes is likely limited by increased energetic demands of thermoregulation at colder ambient temperatures or by food availability, particularly as ice and snow cover limit access to aquatic or agricultural foods (Jorde et al. 1983). Isolating the role of lower ambient temperatures from reduced

\footnotetext{
${ }^{1}$ Department of Wildland Resources, Utah State University, Logan, UT.

${ }^{2}$ Intermountain West Joint Venture, United States Fish and Wildlife Service, Missoula, MT.

${ }^{3}$ E-mail: tony.roberts@aggiemail.usu.edu
} 
food availability is often difficult. Prior studies of the effect of temperature and food availability on wintering abundance were confounded by ice and snow cover that limit available food (Nichols et al. 1983, Schummer et al. 2010). The Great Salt Lake (GSL), Utah, provides a unique opportunity to examine these competing variables in that the lake's hypersaline water allows access to ice-free areas on open waters of the GSL during extended periods of below freezing temperatures.

The GSL and its associated wetlands provide habitat for waterfowl using multiple flyways, mostly the Pacific Flyway but also the Central and Mississippi Flyways, and large populations of ducks use pelagic areas of the GSL in winter (Aldrich and Paul 2002). Midwinter waterfowl species are primarily Northern Shoveler (Anas clypeata) and Common Goldeneye (Bucephala clangula), 2 species with very different feeding habits and habitat associations (Vest and Conover 2011). Predator abundance is also low, consisting mostly of Bald Eagles (Haliaeetus leucocephalus), and mortality from hunters on pelagic areas of the GSL is minimal. Trade-offs associated with foraging in highly saline water and increased thermoregulatory demands associated with northern-latitude climatic conditions may make it difficult for some ducks to survive the winter or may reduce their body condition to levels that would preclude migration or subsequent breeding.

The objectives of this research were to examine the importance of the GSL as a waterfowl wintering area and identify primary variables that influence wintering duck population size on the GSL. We used 7 years of aerial survey data to evaluate wintering duck abundance on open water areas of the GSL, with a focus on Northern Shovelers and Common Goldeneye, the most abundant species on the GSL during winter. We hypothesized that GSL elevation, ambient temperatures during winter, and continental population size would have larger impacts on focal species abundance at GSL than food quantity.

\section{Study Area}

The Great Salt Lake (GSL) is the fourth largest terminal lake in the world and a dominant water feature within the western United States (Arnow and Stephens 1990). The ecosystem covers nearly 780,000 ha when at a lake elevation of $1280 \mathrm{~m}$ and consists of saline open water and brackish and freshwater wetlands. Salinity across the GSL is variable due to concentrated areas of freshwater inflow and anthropogenic alterations of water exchange. By mid-December, freshwater wetlands and low salinity bays, such as Bear River Bay, are usually frozen and habitat availability is restricted to hypersaline open water bays. The high salinities of the GSL support populations of only 2 aquatic invertebrates: brine shrimp (Artemia franciscana) and brine flies (Ephydra spp.). Densities of brine shrimp and their cysts vary spatially, with numbers lowest in areas with less saline water, though cysts float in masses throughout the GSL. Brine fly larvae are found primarily along hard benthic substrates above the anoxic deep brine layer, and larvae densities are 10 times higher on bioherm and mud substrates than on sand substrates (Collins 1980).

The most abundant waterfowl species during winter on the GSL are Northern Shoveler and goldeneye (Common and Barrow's [Bucephala islandica]), and our analysis focused on these species. Prior research (Vest and Conover 2011, Roberts and Conover 2014) has demonstrated that these species feed on halophiles and do not use the GSL strictly as a resting area away from predators and hunters. Other waterfowl species on the GSL during late fall and winter include Mallard (Anas platyrhynchos), Northern Pintail (Anas acuta), and Green-winged Teal (Anas crecca).

\section{Methods}

We conducted monthly aerial surveys of waterfowl on the GSL during 7 winters, from December through March: 2004-2005, 20052006, 2009-2010, 2010-2011, 2011-2012, 20122013, and 2013-2014. Surveys were conducted from a fixed-wing aircraft traveling approximately $150 \mathrm{~km} \cdot \mathrm{h}^{-1}$ at about $60 \mathrm{~m}$ above the water. Surveys began within 1 hour of sunrise and were generally completed within 5 hours. Surveys were not conducted when adverse weather conditions existed (e.g., rain, snow, fog) or when wind speeds were $>13 \mathrm{~km} \cdot \mathrm{h}^{-1}$ because whitecap waves reduced visibility of birds. To better estimate population size, we stratified the GSL into 7 strata based on salinity differences and geographic features of the 


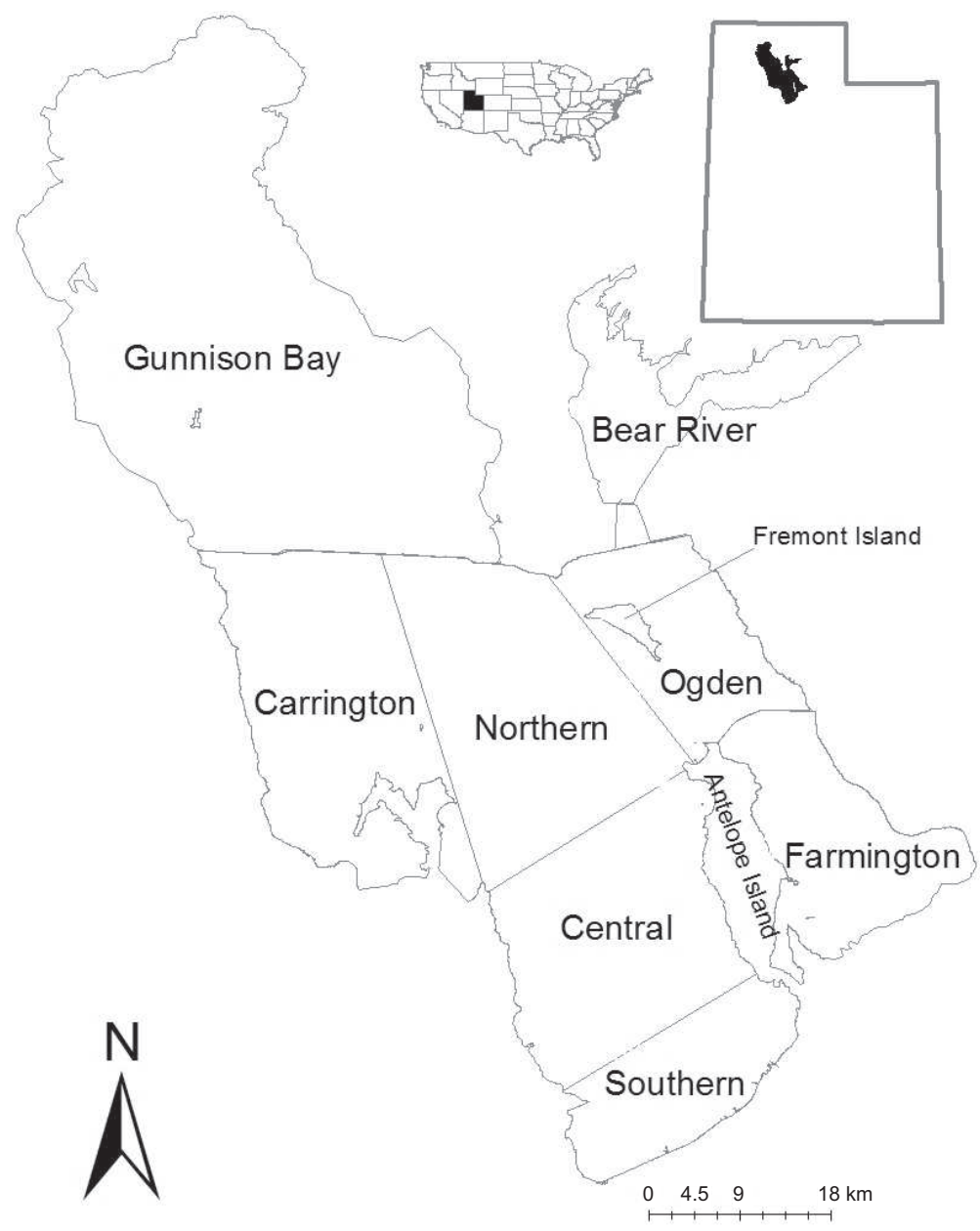

Fig. 1. Map of the Great Salt Lake, Utah, and the strata used in aerial surveys of wintering duck populations.

lake. Strata were Bear River, Carrington, Central, Farmington, Northern, Ogden, and Southern (Fig. 1). We did not utilize the Gunnison Bay stratum during 2009-2014 as our initial survey work (2004-2006) determined there was sparse use of this region by avian species during winter due to salinities near saturation (on average about $27 \%$ salt in the water; Vest 2013). Thus, stratum counts from Gunnison Bay during 2004-2006 were not used in this analysis. Within each stratum, transects were placed $500 \mathrm{~m}$ apart, running east to west. Each month, transects were chosen randomly without replacement and constrained so adjacent transects were not surveyed during the same month. We counted all ducks within a band of $250 \mathrm{~m}$ on each side of the plane; we counted Common and Barrow's Goldeneye as a single group (i.e., goldeneye) due to morphological similarities, but Barrow's Goldeneye are likely a small, though unknown, portion of goldeneye on the GSL during winter (Vest 2013). We did not correct for visibility bias because all transects were located on open expanses of water.

We used Program R for all statistical analyses (R Core Team 2012) and analyzed aerial stratified survey data with individual transects as sample units. Total population abundance estimates and standard errors were calculated for total ducks, Northern Shoveler, and goldeneye for each survey using the SURVEY package (Lumley 2004). We provide estimates of population abundance to illustrate the importance of the GSL to wintering ducks in a regional and national context. 
We modeled the peak population estimate of Northern Shovelers, goldeneye, and total ducks among the 7 years surveyed. We modeled peak duck population against GSL elevation in October, the continental breeding population of Northern Shovelers, Common Goldeneye, or Mallards (to represent the entire duck breeding population), average temperature December through March, brine shrimp abundance in October, brine shrimp cyst abundance in October, and brine fly abundance in August. Invertebrate density data were collected twice a month at 17 sites across the GSL by the Utah Division of Wildlife Resources as described by Belovsky et al. (2011). Although brine fly larvae densities were highest on bioherm substrates (Collins 1980), substrate densities were unavailable. Instead, we used density of brine fly larvae in the water column as a representation of relative substrate density. Timing of food variable measurements was used to represent the period when these food items peaked in density (i.e., the maximum amount available to wintering ducks)—October for brine shrimp adults and cysts and August for brine fly larvae (Belovsky et al. 2011).

We used lake elevation in October as a measure of habitat availability for wintering ducks. October is when freshwater inputs increase at the end of agricultural irrigation season and hence represented the minimum habitat available during winter. Within the shallow water basin of the GSL, small changes in surface elevation result in large changes in surface area, and hence available habitat for birds. Continental population estimates for each species were totals from the United States Fish and Wildlife Service traditional survey area, where birds using the GSL likely spent the previous summer (Roberts and Conover 2015). Air temperature variables were averaged among weather stations at the Salt Lake City International Airport in Salt Lake City and Hat Island in the northwest section of the GSL during the months we surveyed.

We evaluated a set of a priori models for the population of Northern Shovelers, goldeneye, and total ducks on the GSL using each individual predictor variable. We used a single independent variable in each model for a total of 6 models of among year variation in peak duck population abundance. We ranked models using second-order Akaike's information criterion $\left(\mathrm{AIC}_{c}\right)$ and examined output statistics, including $\Delta \mathrm{AIC}_{c}$ (difference between $\mathrm{AIC}_{c}$ of the current model and minimum $\mathrm{AIC}_{c}$ in the model set), and model weight ( $w$; Burnham and Anderson 2002). Our discussion is focused on the top model as ranked by $\mathrm{AIC}_{c}$ and models with a $\Delta \mathrm{AIC}_{c}$ value $\leq 2$. We also assessed the fit of models by calculating an adjusted coefficient of determination (adjusted $r^{2}$ ).

\section{RESUlTS}

We conducted survey flights in 27 of the 28 months available during the 7 winters of this study. The estimated abundance of total ducks on the GSL during December-March ranged from a high of $>270,000$ to a low of near 11,000 and was highly variable from year to year (Table 1). Northern Shoveler abundance estimates ranged from $>200,000$ to none detected, and goldeneye abundance estimates ranged from approximately 44,000 to 1000 . The precision of abundance estimates was generally poor, with coefficient of variation (CV) ranging from $18 \%$ to $60 \%$ for all months.

Six independent variables were examined for their influence on yearly duck peak abundance on the GSL. Yearly duck peak abundance was most influenced by a positive relationship with winter temperature $\left(w=0.60, r^{2}=0.42\right.$; Fig. 2), with the next noncompetitive model being a positive relationship with the continental breeding population of Mallards (Table 2). Competitive models of peak Northern Shoveler abundance included positive relationships with GSL elevation $\left(w=0.64, r^{2}=0.57\right.$; Fig. 3$)$ and density of brine shrimp cysts $\left(w=0.25, r^{2}\right.$ $=0.44$; Table 2 ). Competitive yearly models of goldeneye peak abundance included a negative relationship with the continental population of goldeneye $(w=0.33)$ and a positive relationship with brine fly larvae abundance $(w=0.32$; Table 2$)$. Both goldeneye models displayed poor fit, with adjusted $r^{2}$ values approximately 0.19 (Table 2 ).

\section{Discussion}

High estimates of duck abundance during December and January indicate the GSL is a notable wintering site in addition to its significance during fall and spring migration (Kadlec and Smith 1989). The estimated population of wintering Northern Shovelers on the GSL (up to 200,000 ) represented $1 \%-3 \%$ of the continental 

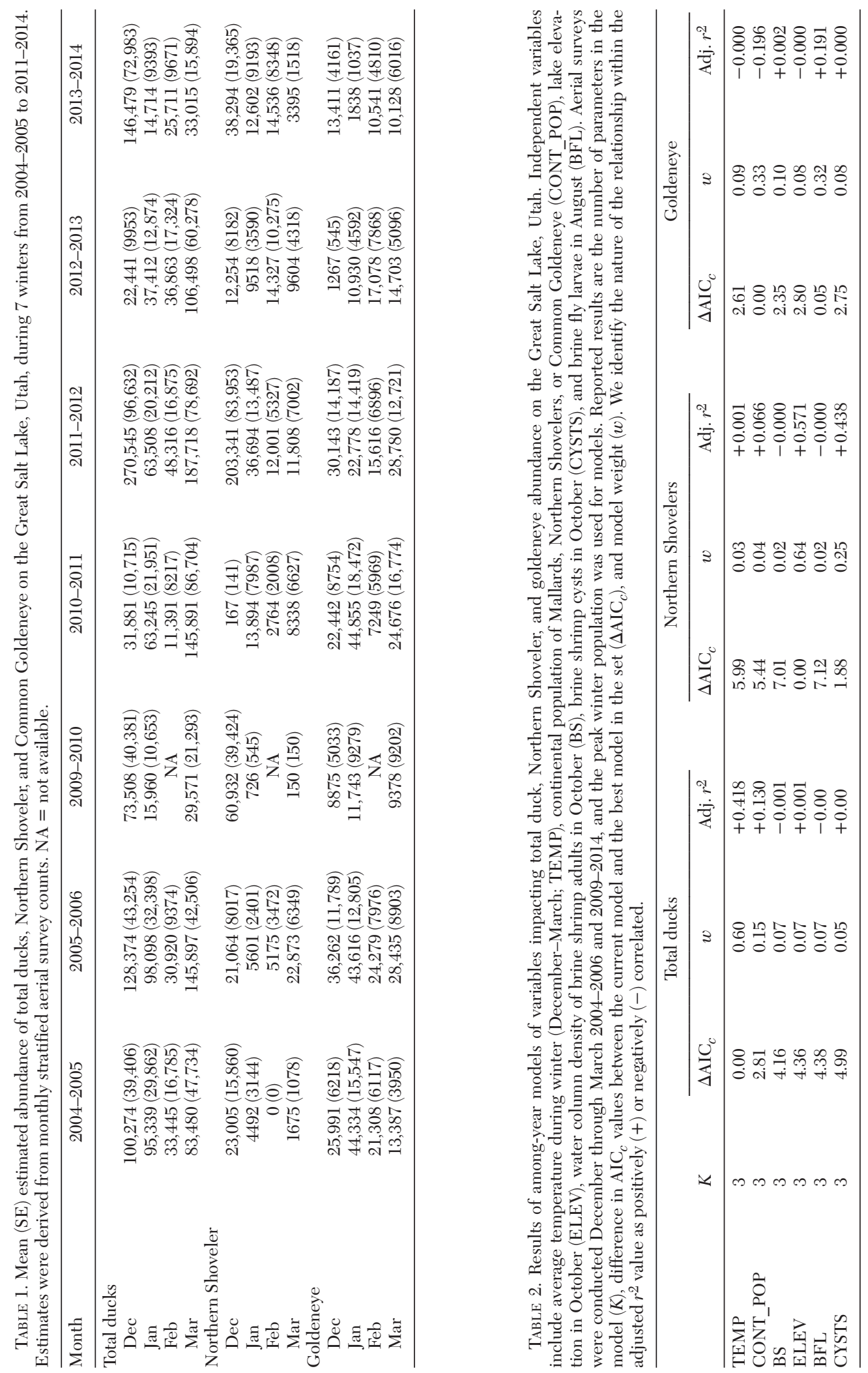


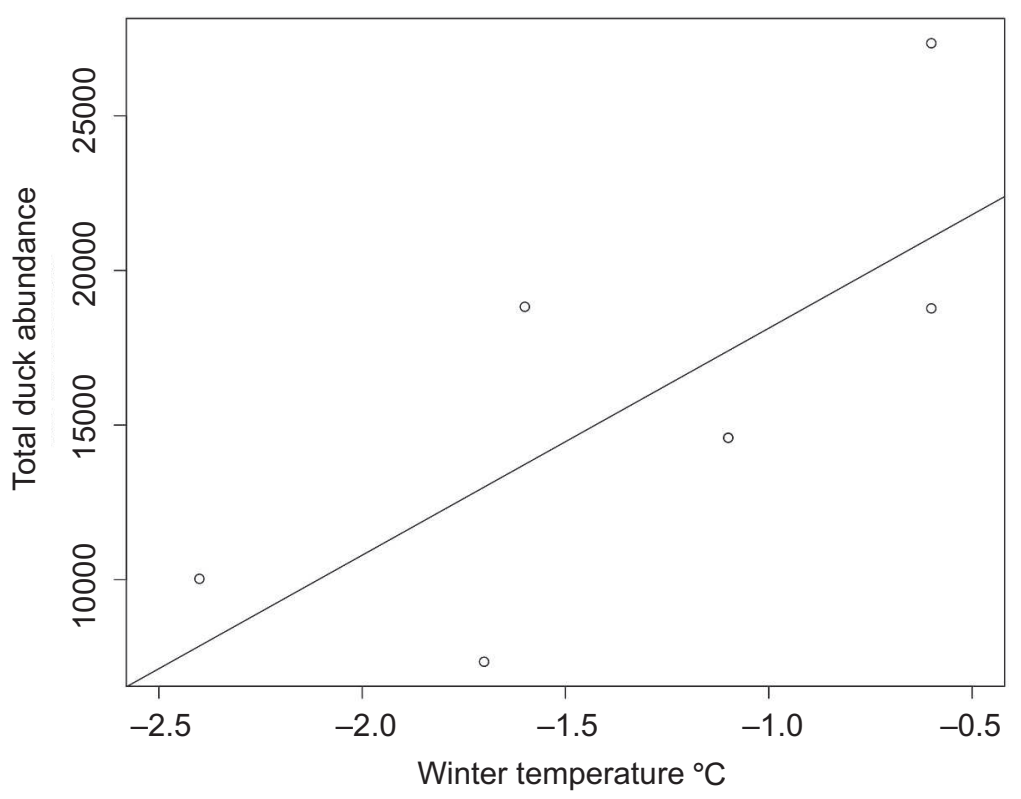

Fig. 2. Influence of average winter (December-March) temperature $\left({ }^{\circ} \mathrm{C}\right)$ during winter on abundance of total waterfowl on the Great Salt Lake, Utah. Data were collected during 7 winters from 2004-2005 to 2011-2014. Only 6 points display on the figure due to similar plot coordinates for 2 years (2005 and 2010 had a peak duck abundance of near 146,000 and an average temperature of $\left.-1.1^{\circ} \mathrm{C}\right)$.

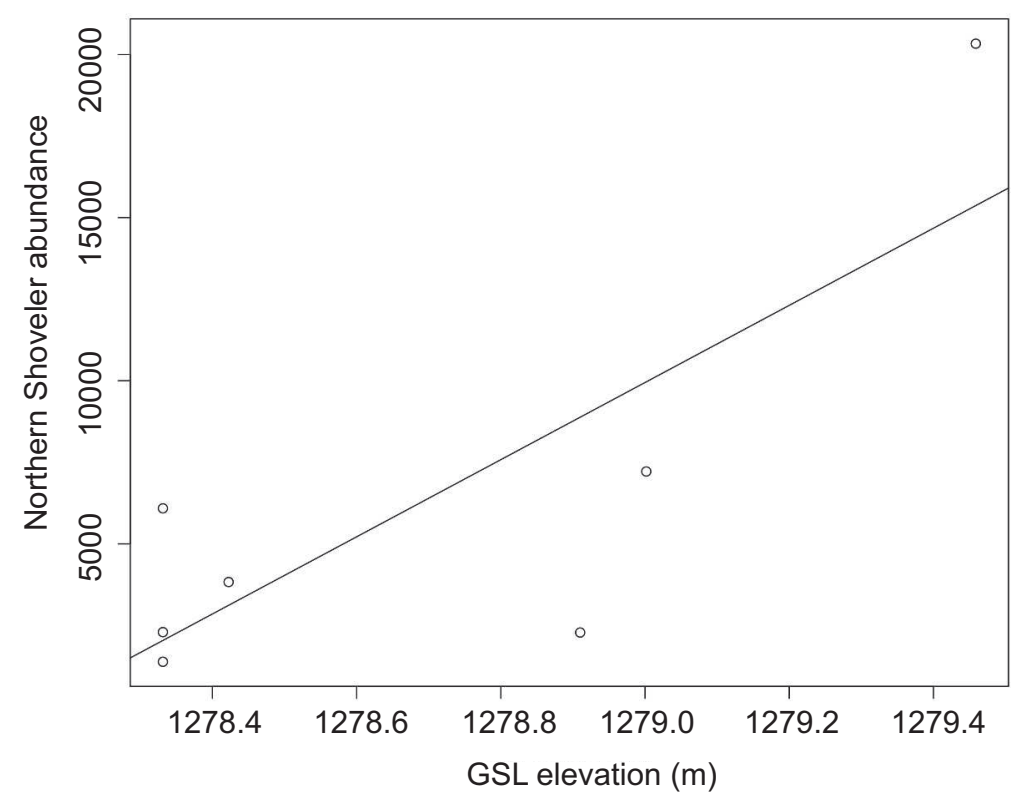

Fig. 3. Influence of the elevation of the Great Salt Lake, Utah, in October on Northern Shoveler peak wintering abundance. Data were collected during 7 winters from 2004-2005 to 2011-2014. 
Northern Shoveler population based on breeding estimates from the United States Fish and Wildlife Service traditional survey area (Zimpfer et al. 2013). Our peak winter counts of ducks indicate the GSL hosts on average $10 \%$ of the Pacific Flyway wintering population of Northern Shovelers (Olson 2014). In addition, estimates of wintering goldeneye populations $(9000-44,000)$ indicate the GSL may host, on average, up to $60 \%$ of the Pacific Flyway wintering goldeneye population (Olson 2014). This represents 1\%-9\% of the traditional survey area breeding population. Pacific Flyway midwinter surveys do not include open waters of the GSL (B. Stringham, Utah Division of Wildlife Resources, personal communication) so estimates from those counts are likely low considering the numbers of goldeneye observed in this study that are not accounted for in midwinter surveys.

Extensive complexes of privately and publicly managed freshwater wetlands $(>85,000$ ha) lie adjacent to the GSL and are important habitats for migratory waterfowl (Kadlec and Smith 1989, Aldrich and Paul 2002). However, managed wetland complexes were not included in these surveys because the primary objective was to elucidate patterns of waterfowl use in the main body of the GSL and those bays with hydrologic connectivity that have not been surveyed by other programs. Thus, estimates of continental significance from this study should be considered conservative and may underestimate the extent of the flyway population using the GSL ecosystem. Until recently, the GSL was not known to be a major wintering area for ducks in the Pacific Flyway because its open water areas had not been surveyed. If managers' goals are to accurately monitor changes in wintering duck abundance, we suggest including open water surveys in midwinter counts, particularly for goldeneye species.

The GSL is an ideal system to examine the influence of weather and food resources on wintering duck density because habitat availability is relatively constant during winter due to the absence of persistent ice cover in the hypersaline water. Previous research on wintering abundance of ducks in North America has focused on wintering Mallards, using that species as a surrogate for overall dabbling duck (Anas spp.) abundance. In the Mississippi Alluvial Valley, precipitation and cold weather (Nichols et al. 1983), habitat availability (Reinecke et al. 1987), and habitat complexity (Pearse et al. 2012) all influence Mallard abundance and distribution during winter. Our results are consistent with other studies regarding the influence of ambient temperature on total duck abundance in winter (Baldassarre and Bolen 2006). Previous research has shown that winter severity indices that include snow cover, rather than temperature alone, may best explain duck abundance (Schummer et al. 2010). However, ice and snow on the GSL generally does not limit food availability after freshwater marshes freeze, and our results suggest that for total duck populations, thermoregulatory demands are more important than food abundance in the choice to continue migration. In contrast, for individual species, food abundance seemed to influence wintering abundance.

Northern Shovelers may be able to remain at the GSL during winter because their unique bill morphology and feeding style (DuBowy 1996) allow them to efficiently forage on floating masses of brine shrimp cysts (Vest and Conover 2011) and balance any adverse physiological or osmoregulatory impacts (Bennett and Hughes 2003). Northern Shoveler abundance was positively influenced by brine shrimp cyst abundance. Cysts comprised about $77 \%$ of Northern Shoveler diet in late winter (Vest and Conover 2011, Roberts and Conover 2014) and are the primary available food source on open waters of the GSL. Cysts are harvested commercially so it is important to continue monitoring the response of Northern Shoveler populations to changes in cyst abundance. Populations of Northern Shovelers wintering on small marshes in western France were also influenced by food abundance (Guillemain et al. 2000). In contrast to our results, DuBowy (1988) reported that Northern Shovelers are less affected by food abundance during winter than other Anas species. This is likely because there was a higher diversity of food types limiting to other species in the Central Valley of California, and Northern Shovelers were able to exploit a wider variety of foods.

Goldeneyes are efficient at osmoregulation (Bennett and Hughes 2003), a characteristic that makes their use of hypersaline areas possible. Goldeneyes occur in saline habitats in much of their wintering range (Bellrose 1976). 
Goldeneye abundance among years on the GSL was positively associated with food (brine fly larvae) abundance. Brine fly larvae are a principle food source of wintering goldeneye (Vest and Conover 2011), but factors influencing brine fly larvae abundance are not fully understood. The relationship may have been weak due to our use of water column density as a proxy for substrate density of brine fly larvae.

The invertebrates found in the GSL are higher in energy content than many wetland plant seeds found in other wintering areas (Caudell and Conover 2006, Dugger et al. 2007). High-energy foods along with increased foraging efficiency can reduce the rate of lipid loss during extended cold periods (Schummer et al. 2012), and within species, heavier individual ducks have higher survival rates (Heitmeyer 1995). High densities of nutritious food may explain large numbers of ducks utilizing a site that is colder and more saline than typical wintering areas. This is particularly true for species such as Northern Shovelers and goldeneye that have morphological or physiological adaptations to efficiently exploit foods in hypersaline habitats.

Large-scale climatic conditions seem to have a larger influence on the abundance of total wintering ducks on the GSL than food availability. Despite abundant food, colder temperatures still resulted in fewer wintering ducks. We found that Northern Shoveler peak winter population was positively associated with GSL elevation. Waterfowl distribution and abundance in winter generally respond positively to increases in foraging and aquatic habitat availability at multiple spatial scales (Nichols et al. 1983, Heitmeyer and Vohs 1984, Cox and Afton 2000, Fleskes et al. 2002). Drought conditions in the GSL region extended throughout much of the study, with only a couple years of high snowfall, the most abundant form of precipitation in this region. This caused a decline in GSL surface elevations and reduced wetland availability (Stephens 1990, Wilkowske et al. 2003, Olson 2005). For example, because precipitation in the GSL watershed increased in 2005 from 2004, lake elevations consequently increased and wetland habitat conditions adjacent to the GSL improved because of greater availability of water (Olson 2006). Our perspective is that the wintering waterfowl population on the GSL is a function of not only environmental and biological processes at GSL but also other regional- and continental-scale factors within and between annual cycle events.

\section{ACKNOWLEDGMENTS}

This research was supported by Utah Division of Wildlife Resources (UDWR), Great Salt Lake Ecosystem Program, Utah Agricultural Station, and Utah State University. The manuscript was approved as journal paper number 8566. We thank J. Luft, T. Aldrich, J. Dolling, R. Hansen, J. Neill, C. Perschon, and J. Van Leeuwen for their assistance as observers in aerial surveys. We especially thank UDWR pilots C. Schaffer and C. Hunt for their expert pilot services, cooperation, and patience in conducting and scheduling aerial surveys. We thank J. Bissonette and J. Neill for comments on previous drafts.

\section{Literature Cited}

Aldrich, T.W., AND D.S. Paul. 2002. Avian ecology of Great Salt Lake. Pages 343-374 in J.W. Gwynn, editor, Great Salt Lake: an overview of change. Utah Department of Natural Resources, Salt Lake City, UT.

Arnow, T., And D. Stephens. 1990. Hydrologic characteristics of the Great Salt Lake, Utah: 1847-1986. United States Geological Survey Water-Supply Paper No. 2332, U.S. Government Printing Office, Washington, DC.

Baldassarke, G.A., And E.G. Bolen. 2006. Waterfowl ecology and management. 2nd edition. Krieger Publishing, Malabar, FL.

Bellrose, F.C. 1976. Ducks, geese, and swans of North America. Stackpole Books, Harrisburg, PA.

Belovsky, G.E., D. Stephens, C. Perschon, P. Birdsey, D. Paul, D. Naftz, R. Baskin, C. Larson, C. MelLison, J. LufT, ET AL. 2011. The Great Salt Lake ecosystem (Utah, USA): long term data and a structural equation approach. Ecosphere 2:1-40.

Bennett, D.C., And M.R. Hughes. 2003. Comparison of renal and salt gland function in three species of wild ducks. Journal of Experimental Biology 206: 3273-3284.

Burnham, K.P., And D.R. Anderson. 2002. Model selection and multi-model inference: a practical information theoretic approach. Springer Press, New York, NY.

Caudell, J.N., And M.R. Conover. 2006. Energy content and digestibility of brine shrimp (Artemia franciscana) and other prey items of Eared Grebes (Podiceps nigricollis) on the Great Salt Lake, Utah. Biological Conservation 130:251-254.

Collins, N. 1980. Population ecology of Ephydra cineria Jones (Diptera: Ephydridae), the only benthic metazoan of the Great Salt Lake, U.S.A. Hydrobiologia 68:99-112.

Cox, R.R., JR., AND A.D. AfTON. 2000. Predictable interregional movements by female Northern Pintails during winter. Waterbirds 23:258-269. 
Dalby, L., A.D. Fox, I.K. Petersen, S. Delany, and J. Svenning. 2013. Temperature does not dictate the wintering distributions of European dabbling duck species. Ibis 155:80-88.

DuBowy, P.J. 1988. Waterfowl communities and seasonal environments: temporal variability in interspecific competition. Ecology 69:1439-1453.

DuBowy, P.J. 1996. Northern Shoveler (Anas clypeata). Account 217 in A. Poole, editor, The Birds of North America. Cornell Lab of Ornithology, Ithaca, NY.

Dugger, B.D., M.L. Moore, R.S. Finger, and M.J. Petrie. 2007. True metabolizable energy for seeds of common moist-soil plant species. Journal of Wildlife Management 71:1964-1967.

Fleskes, J.P., R.L. Jarvis, and D.S. Gilmer. 2002. Distribution and movements of female Northern Pintails radiotagged in San Joaquin Valley, California. Journal of Wildlife Management 66:138-152.

Guillemain, M., H. FriTZ, AND N. Guillon. 2000. Foraging behavior and habitat choice of wintering Northern Shoveler in a major wintering quarter in France. Waterbirds 23:353-363.

Heitmeyer, M.E. 1995. Influences of age, body condition, and structural size on mate selection by dabbling ducks. Canadian Journal of Zoology 73: 2251-2258.

Heitmeyer, M.E., and P.A. Vohs Jr. 1984. Distribution and habitat use of waterfowl wintering in Oklahoma. Journal of Wildlife Management 48: $51-62$.

HEPP, G.R., AND J.E. HinEs. 1991. Factors affecting winter distribution and migration distance of wood ducks from southern breeding populations. Condor 93: 884-891.

Jorde, D.G., G.L. Krapu, and R.D. Crawford. 1983. Feeding ecology of mallards wintering in Nebraska. Journal of Wildlife Management 47:1044-1053.

Kadlec, J.A., And L.M. Smith. 1989. The Great Basin marshes. Pages 451-474 in L.M. Smith, R.L. Pederson, and R.M. Kaminski, editors, Habitat management for migrating and wintering waterfowl in North America. Texas Tech University Press, Lubbock, TX.

Lumley, T. 2004. Analysis of complex survey samples. Journal of Statistical Software 9:1-19.

Miller, M.R., E.G. Burns, B.E. Wickland, and J.M. EADIE. 2009. Diet and body mass of wintering ducks in adjacent brackish and freshwater habitats. Waterbirds 32:374-387.

Nichols, J.D., K.J. Reinecke, and J.E. Hines. 1983. Factors affecting the distribution of mallards wintering in the Mississippi Alluvial Valley. Auk 100:932-946.

Olson, B.E. 2005. Bear River Migratory Bird Refuge annual habitat management plan: 2005. U.S. Department of the Interior, Fish and Wildlife Service, Brigham City, UT.

OLson, B.E. 2006. Bear River Migratory Bird Refuge annual habitat management plan: 2006. U.S. Department of the Interior, Fish and Wildlife Service, Brigham City, UT.
OLSON, S.M. 2014. 2014 Pacific Flyway data book. U.S. Fish and Wildlife Service, Division of Migratory Bird Management, Portland, OR.

Ouellet, J.F., M. Guillemette, and M. Robert. 2010. Spatial distribution and habitat selection of Barrow's and Common Goldeneyes wintering in the St. Lawrence marine system. Canadian Journal of Zoology 88:306-314.

Pearse, A.T., R.M. Kaminski, K.J. Reinecke, and S.J. DinsmoRe. 2012. Local and landscape associations between wintering dabbling ducks and wetland complexes in Mississippi. Wetlands 32:859-869.

R Core Team. 2012. R: a language and environment for statistical computing. R Foundation for Statistical Computing, Vienna, Austria.

Reinecke, K.J., C.W. Shaiffer, and D. Delnicki. 1987. Winter survival of female mallards in the lower Mississippi Valley. Transactions of the North American Wildlife Natural Resources Conference 52:258-263.

Roberts, A.J., And M.R. Conover. 2014. Diet and body mass of ducks in the presence of commercial harvest of brine shrimp cysts in the Great Salt Lake, Utah. Journal of Wildlife Management 78:1197-1205.

RoberTs, A.J., AND M.R. CONOVER. 2015. Breeding origins of Northern Shovelers (Anas clypeata) wintering on the Great Salt Lake, Utah. Wilson Journal of Ornithology 127:233-238.

Schummer, M.L., R.M. Kaminski, A.H. Raedeke, and D.A. Graber. 2010. Weather-related indices of autumn-winter dabbling duck abundance in middle North America. Journal of Wildlife Management 74:94-101.

Schummer, M.L., S.A. Petrie, R.C. Bailey, and S.S. BADZINSKI. 2012. Factors affecting lipid reserves and foraging activity of Buffleheads, Common Goldeneyes, and Long-tailed Ducks during winter at Lake Ontario. Condor 114:62-74.

Stephens, D.W. 1990. Changes in lake levels, salinity and the biological community of Great Salt Lake (Utah, USA), 1847-1987. Hydrobiologia 197:139-146.

VEST, J.L. 2013. Winter ecology of waterfowl on the Great Salt Lake, Utah. Doctoral dissertation. Utah State University, Logan, UT.

Vest, J.L., AND M.R. Conover. 2011. Food habits of wintering waterfowl on the Great Salt Lake, Utah. Waterbirds 34:40-50.

Wilkowske, C.D., D.V. Allen, and J.V. Phillips. 2003. Drought conditions in Utah during 1999-2002: a historical perspective. U.S. Department of the Interior, U.S. Geological Fact Sheet 037-03; [accessed 9 November 2013]. http://pubs.usgs.gov/fs/fs-037-03/

Zimpfer, N.L., W.E. Rhodes, E.D. Silverman, G.S. Zimmerman, and K.D. Richkus. 2013. Trends in duck breeding populations, 1955-2013. U.S. Fish and Wildlife Service, Division of Migratory Bird Management, Laurel, MD.

Received 5 June 2015 Accepted 30 September 2015 